\title{
Behaviour of Reference in Translation
}

\author{
Mohamed Abdou Moindjie \\ School of Languages, Literacies and Translation, Universiti Sains Malaysia
}

Received: 18-04-2015

Accepted: 12-06- 2015

Published: 31-07- 2015

doi:10.7575/aiac.ijclts.v.3n.3p.1

URL: http://dx.doi.org/10.7575/aiac.ijclts.v.3n.3p.1

\begin{abstract}
Reference, which is one aspect of cohesion, may affect or enhance cohesiveness in its behaviour in translation. This study is an investigation of the behaviour of reference in translating from Arabic into English and French. The texts which are used as corpuses are literary texts whose findings are expected to be reflexive to other genres. The study reveals that reference, in translation depends often on certain language peculiarities; it is seldom depends on the translator's choices. It is found that English is more cohesive in translation than Arabic and French due to some of its peculiarities. Although the Arabic language and the French languages have different peculiarities, they are found to have more in common as far as translating reference is concerned. The translators' familiarity with the language peculiarities would make them avoid pitfalls and handle reference perfectly, which enhances more translation in terms of meaning, cohesiveness, and coherence. It is observed that the translators' unfamiliarity with the languages peculiarities may affect reference in terms of meaning, cohesiveness, and coherence. It can, therefore, create translations in that reference is often found to be determined by language peculiarities.
\end{abstract}

Keywords: Cohesion, Reference Translatability, Language Peculiarity, Syndeton, Asyndeton, Hypothaxis

\section{Introduction}

Descriptive translation studies have witnessed a boom after Holmes' paper presented in 1972, which comes to give a shape to translation and give a meaning on the controversial translation debate on word-for-word or sense-for-sense which existed many centuries ago. This has turned translational operations, according to Mundy (2001: 17-29), to new approaches which describe meanings scientifically and "put together systematic taxonomies of translation phenomena."Jones (1997) states that the Problems of translation are either semantic, structural or metalinguistic. Halliday (2004: 524) points out that "the organization of text is semantic rather than formal." This means that a text is totally a semantic unit. This research has been carried out due to some semantic problems apropos of cohesion and cohesiveness in translation. A source text is written in certain cohesive ways so as to convey a coherent message to the source language readers. However, the translation is not done by the writer of the source text. It is done by another person. Therefore, the translation methods and procedures, translatability and functionality need to be investigated. As far as reference is concerned, it is a grammatical aspect dealing with cohesiveness, which an encoder and a decoder should handle well. Vinay and Darbalnet (1995: 9-10) consider comparativeness paramount in developing translation theory in that it "examines how the constituents parts of a system function when they rendered ideas expressed in other language."Moreover, this research is on a par with the call of Toury(1985) and Toury (1995) for putting in practical systematic descriptive approaches rather than traditional isolated studies. In the same vein, Lambert and Gorp (1985) point out the feasibility and the foci of this kind of research. They write:

Since translation is essentially the result of selection strategies from and within communication systems, our main task will be to study the priorities- the dominant norms and models- which determine these strategies. The basic 'acceptable' versus 'adequate' dilemma will, in turn, lead to more concrete questions concerning priorities at different levels of both systems. The translation process as well as the resulting text and its reception can be studied from different points of view, either in a macro-structural or in a micro-structural way, focusing on linguistic patterns of various types, literary codes, moral, religious or other non-literary patterns (Lambert and Gorp, 1985: 46).

This paper describes and compares qualitatively the behaviour and translatability of one aspect of cohesion, which is reference. The paper is trying to achieve the following objectives:

(a) To investigate the behaviour of reference in translation.

(b) To compare reference occurrences from the ST to the TTs.

(c) To determine phenomena that may occur in the translation process.

This investigation is carried out to test the hypothesis that the translator may be biased in handling norms relative to reference cohesiveness. This paper limits its self, due to the enormous aspects of macrostructures and microstructures mentioned by Lambert and Gorp (1985), to one aspect of the microstructure of a text, reference, which is a linguistic item. This paper is intended to show translators, interpreters, linguists, and language learners how reference may behave and how it is handled in translation. It is also intended to be reflexive to other genres. The paper is composed of the 
Introduction, methods and organization, synopsis of the novels, literature review, results, analysis, modelling, and conclusion.

\section{Organization and Methods}

According to the comparative study described by Toury (1985) and according to the foci of this study, following Lambert and Gorp (1985), the corpora of this research consists of one SL, Arabic and two TTs of two different languages, English and French. Although the corpora exist in many different languages of the world, there are reasons for this choice. The choice of doing the research on the above-mentioned three languages is not only for convenience but also for the fact that they are among the six official languages of the United Nations; they are languages that are officially used in many countries and spoken by many people in the world.

The study opts for the novel rather than other literary hyponyms like poetry and drama for convenience and for its openness and flexibility in terms of content and form, which can be reflexive to other types and genres. The first ST is a novel from Naguib Mahfouz' omnibus (المؤلفات الكاملة), زقاق المدق (Zukāk el- Midaq) [1] by Naguib Mahfouz 1947 and published by Librairie du Liban in 1990. The translations that are studied are Midaq Alley [2] translated by Trevor Le Gassick, and published by Heinemann Educational Books in 1975, and Passage des Miracles [3] translated by Antoine Cottin, and published by Éditions Sindbad in 1970. The second novel is entitled موسم الحجرة إلى الثمال (Mawsim el-Hiğrailā ash-Shamāl) [4] by Tayeb Salih (1967); the translations are entitled Season of Migration to the North[5] translated by Denys Johnson-Davies and published in 1969 by Heimann, and Saison de la Migration vers le Nord [6] translated by Abdelwahab Meddeb and Fady Noun and published in 1983 by Sindbad. The second novel is meant for consolidating the findings. That is, it is to see whether the findings are consistent or inconsistent, which will permit some generalizations in terms of languages and translations. The findings are expected to lend themselves to translation modeling, and contribute to translation studies.

Naguib Mahfouz is chosen, compared to other Arab writers like Tawfik El-hakim, Taha Hussain, etc, for his great achievements in the Arabic novel writing as a Nobel Prize laureate. Mahamoud (1973) discusses that Naguib Mahfouz belongs to the second generation of Arabic novelists. Although he is not one of the pioneers of Arabic novels, he has become "the leading novelist in Arabic today." He has written many novels, but his Midaq Alley is opted for carrying this study because, according to Allen (1997: 457), it is the most representative, famous, and popular of his work.

Tayeb Salih is also chosen because of his literary achievements as one of the famous writers of the Arab world. He has written many novels like Bandarchah, The Wedding of Zain, etc., but Season of Migration to the North is chosen because, Sadgrove (1997: 737) points out, it is his master piece, which made his reputation.

The corpus is, therefore, justified and selected following the above mentioned characteristics of the genre per se, the literary leadership, universal recognition of the writers, and the works as the more representative and popular of the two writers.

The analysis is carried out on the Arabic texts, English texts and French texts. The novels are studied as a whole, and extracts that reflect the problems of reference are identified, selected, and collected. Reflective extracts are selected and collected from the two novels and their translations respectively. This is done after analysing the ST and the TTs as a whole. The selection of the extracts is done in two stages. The first stage is a selection of reflective extracts concerning reference in the STs. The second stage is a selection of reflective extracts in the TTs. For that reason, the selection procedure is not done randomly; it is done systematically and progressively from the beginning of the novels to their ends.

The extracts will be labelled as source and target. AST stands for Arabic source text; ETT stands for English target text; and FTT stands for French target text. This is meant to help the reader to recognize, in the discussion, the language discussed since the study deals with three languages, i.e. Arabic, English, and French. Data identification is done in stages. The first procedure is to identify the data. To do so, the entire texts under study are thoroughly studied. The second stage the data are categorized in the AST, ETT and FTT. Then the data are analysed.

Reference occurrences are presented in tables; they are underlined and highlighted in bold. If the analysed aspect does not surface in any of the texts, its presumed and possible location is only underlined for better clarification. Moreover, many examples of reference occurrences are found. Due to space constraints and words limit of a paper, these other occurrences are not reproduced in the body of the article. However, the pages numbers containing these examples are given on the appendices.

To identify language similarities, differences, peculiarities, and translation choices, every occurrence of every category in the ASTs is compared to the same category in the ETTs and FTTs. Then the same category occurrence is compared between the ETTs and the FTT.

The analyses have been done manually for qualitative reasons. This textual translation analysis is done by using this methodology adapted from Halliday and Hasan(1976), Charolles (1978), Toury (1985), and Lambert and Gorp (1985). Two different novels are used in order to justify the findings. Thereupon, some textual analyses which have already been done on the researcher's PhD thesis, Moindjie(2006) are taken and used to show the behaviour of reference in translation. The appendices embody the selected pages of the AST, ETT, and FTT.

\section{Literature Review}

Cohesion is a linguistic aspect that links the surface structures of a text. Baker (1992: 218) distinguishes between cohesion and coherence. She defines the former as "the network of surface relations", whose function is to link textual 
surface devices or discourses to others, and the latter as "the network of conceptual relations which underlie the surface text." This shows that there is discrepancy between the two concepts even though they are interrelated. Moreover, Enkvist (1990: 12) argues that a text can be cohesive without being coherent and vice versa. Leech (2008: 29), points out the importance of cohesion in that it deals with independent choices in literary texts. Precisely, he states that "Cohesion is a dimension of linguistic description which is particularly important in the study of literary texts. By this is meant the way in which independent choices at different points of a text correspond with or presuppose one another, forming a network of sequential relations."

Nevertheless, Charolles (1978) believes that a text cannot be coherent if it is not macrostructurally and microstructurally coherent. By macrostructure, he means coherence, and by microstructure he means cohesion. To be coherent and cohesive, he emphasizes, the text must embody four meta-rules: (1) méta-règles de répétition, (2) méta-règles de progression, (3) méta-règles de non-contradiction, and (4) méta-règles de relation. The problem of cohesion as far as translation is concerned is that it is a variable factor. Callow (1974: 30) states that every language has its own peculiar cohesive devices and ways of linking its surface structure. This indicates that some shifts have to be carried out in the translation process. Catford (1965: 73- 82) emphasizes that shifts of cohesive aspects are necessary in translation because there is no equivalence as far as cohesion is concerned.

Blum-Kulka (2000: 313) argues, on the one hand, that shifts are carried out in the cohesive surface structures. The translator's determination of those aspects "can affect the texture as well as the style and meaning" of the text especially the literary one. On the other hand, the translator has to be careful with the deep coherent structures since shifts at that level will make the text lose its "meaning potential" if they are mishandled. The research of cohesion in translation from French language into English language done by Moindjie (2003) shows that, in translation, coherent aspects are not translated. Instead of that, they are always transferred to the TT, and are manifested by cohesive ties, which are determined by certain TL peculiarities.

In order to render the meaning properly, shift is, sometimes, necessary; it can be done on the grammatical, structural, and cohesive levels without changing the meanings of the text. Popovič (1970) points out that translation focuses on transferring "certain intellectual and aesthetic values from one language to another". For that reason the translation process necessitates some shifts relative to those values. He considers translation as a confrontation between literariness and linguistic values. He believes that shift occurs due to language differences concerning literary, linguistic, stylistic, social, and expressive approaches and values, which, on the one hand, the translator has to put into consideration for faithfulness to the author and the text per se, and acceptability of the translation by the readership on the other hand.

The most prominent concept of cohesion is the one introduced by Halliday and Hasan (1976). For them, cohesion deals with the relation between textual semantic components of a text. It does not deal with a structural unit but with a semantic unit in the sense that a text is a semantic unit. They divide cohesion into cohesive categories: (1) reference, (2) substitution, (3) ellipsis, (4) conjunction, and (5) lexical cohesion. The following example from Halliday (1985) illustrates:

Little Boy Blue, come blow your horn!

The sheep's in the meadow, the cow's in the corn.

Where is the boy that looks after the sheep?

(Reiteration)

He's under the haycock, fast asleep.

(Reference)

Will you go wake him? No, not I!

(Ellipsis)

$\underline{\text { For }}$ if I do, he'll be sure to cry (Halliday, 1985: 288).

(Conjunction and Substitution).

Reference is defined in Trask's dictionary, entitled A Student's Dictionary of Language and Linguistics as "the relation between a noun phrase and the person or thing it picks out in the world." In Halliday and Hasan, reference is used similarly but in a more strict way. It does not show a direct relationship between the words and extralinguistic objects, reference is restricted to "identity relationship which holds between two linguistic expressions". Textually, reference is used at the time that the reader feels necessary to get back the identity of a person or thing. This happens by referring to another in the context. Every language has its specific ways of using and understanding reference ties which can direct the reader to refer to other words in order to understand and interpret them. The most useful reference in English and in a lot of other languages is the pronoun which can refer to an entity mentioned before or after in the text. There are other pronouns that play the same role. These are "the, this, and those", which are used to link expressions in a given text.

Halliday and Hasan (1976), classifies reference into situational reference, exophora, and textual reference, endophora. An exophoric reference depends on the context; it refers to items that are context-bound. Unlike the exophora, the endophora refers to another item within the text per se. It is composed of anaphora which refers to an item backward, and cataphora which refers to an item forward. endophora can be either personal reference, demonstrative reference, or comparative reference.

\section{The novels}

The two novels, زقاق المدق(Zukāk el- Midaq) and موسم الحجرة إلى الثمال(Mawsim el-Hiğrailā ash-Shimāl) are written by native speakers of Arabic. They are written in Arabic; they are intended to be read by Arabs and non-Arabs who know Arabic language. The English translations are translated by native speakers of English; they are intended to be read by 
English speakers, be they natives or non-natives. The French translations are translated by native French speakers; they are intended to be read by French speakers, be they natives or non-natives.

\subsection{Synopsis}

\subsubsection{Zukāq el-Midaq}

It describes life in terms of social problems in Egypt. Midag Alley is used as a metonymy of life in Cairo and Egypt. It represents the conflict between tradition and modernity, morality and immorality, patience and impatience, poverty and richness, and the dream of the young for a better life and freedom outside this alley. These doublets have their negative and positive aspects. The main characters Hamida, Abbas al-Helou, Karsha, Hussein Karsha, Ridwān al-Hussein, Saniya Afifi, Salim Alwān, and Father Kāmil represent life in the Midaq. Each character becomes a victim of a social hardship. The Main character, Hamida falls victim to poverty and sexual exploitation, which render her marriage with Abbas impossible; Abbas falls victim to his impatience and tradition, which bring about his death by the English; the rich Salim Alwan falls victim to his concupiscence, which makes him attacked by heart attack. This renders his polygamous intention impossible.

\subsubsection{Mawsim el-Hiğrailā ash-Shimāl}

The novel describes the life of a Sudanese gifted student in the Sudan and outside the Sudan, Egypt and England. This student is Mustafa Sa'eed. He is a torn character between tradition, modernism, and freedom. He has become an instable character despite the knowledge he has acquired in England. He has become a victim to cultural differences, Englishness, and marginalization. He cannot feel at home in his own country. The only person he can trust is the narrator of this story, who has acquired the same English culture like him in England. The story ends mysteriously: he is thought to either commit suicide or be killed.

\section{Result}

The result of this study identifies reference as (a) personal reference, (b) demonstrative reference, and (c) comparative reference.

\subsection{Zukāq el-Midaq}

5.1.1 Personal reference

\begin{tabular}{llll}
\hline Factors & Frequency & & \\
\hline & AST & ETT & FTT \\
Abstractness & 58 & 50 & 84 \\
Syndeton & 75 & 46 & 48 \\
Asyndeton & 24 & 14 & 25 \\
Hypothaxis & 20 & 12 & 44 \\
Interchangeability & & & \\
-reiteration & 33 & 53 & 61 \\
- demonstrative reference & 26 & 0 & 24 \\
\hline
\end{tabular}

\subsubsection{Demonstrative reference}

\begin{tabular}{llll}
\hline Factors & Frequency & & \\
\hline & AST & ETT & FTT \\
Abstractness & 22 & 10 & 36 \\
Syndeton & 9 & 2 & 3 \\
Asyndeton & 3 & 2 & 3 \\
Interchangeability & & & \\
- Personal reference & 5 & 34 & 33 \\
- reiteration & 19 & 5 & 0 \\
- demonstrative reference & 0 & 0 & 32 \\
\hline
\end{tabular}

\section{$\underline{5.1 .3 \text { Comparative reference }}$}

\begin{tabular}{llll}
\hline Factors & Frequency & & \\
\hline & AST & ETT & FTT \\
Comparative reference & 3 & 6 & 3 \\
personal reference & 2 & 0 & 1 \\
reiteration & 0 & 0 & 2 \\
\hline
\end{tabular}


5.2.1 Personal reference

\begin{tabular}{llll}
\hline Factors & Frequency & & \\
\hline & AST & ETT & FTT \\
Abstractness & 5 & 15 & 37 \\
Syndeton & 24 & 13 & 7 \\
Asyndeton & 11 & 16 & 12 \\
Hypothaxis & 3 & 8 & 5 \\
Interchangeability & & & \\
- reiteration & 4 & 11 & 14 \\
- demonstrative reference & 0 & 0 & 8 \\
- substitution & 0 & 2 & 0 \\
- implicitness & 43 & 0 & 0 \\
\hline
\end{tabular}

\subsubsection{Demonstrative reference}

\begin{tabular}{llll}
\hline Factors & Frequency & & \\
\hline & AST & ETT & FTT \\
Abstractness & 1 & 2 & 13 \\
Syndeton & 0 & 1 & 0 \\
Asyndeton & 0 & 1 & 0 \\
Hypothaxis & 0 & 0 & 0 \\
Interchangeability & & & \\
- reiteration & 1 & 0 & 0 \\
- demonstrative reference) & 1 & 1 & 3 \\
\hline
\end{tabular}

\subsubsection{Comparative reference}

\section{Analysis}

\begin{tabular}{llll}
\hline Factors & Frequency & & \\
\hline & AST & ETT & FTT \\
Comparative reference & 1 & 3 & 1 \\
Interchangeability & & & \\
- personal reference & 0 & 0 & 0 \\
- reiteration & 2 & 0 & 2 \\
\hline
\end{tabular}

\subsection{Zukāq el-Midaq}

\subsubsection{Personal reference}

Comparing the texts, it is found that cohesive personal reference is more used in the ETT than the FTT and AST. In the FTT, it is due to the fact that abstractness, syndeton, asyndeton, and subordination affect personal reference. In the $\mathrm{AST}$, it is due to the fact that abstractness, syndeton, asyndeton, and implicitness affect also personal reference. Furthermore, other cohesive ties like reiteration, and demonstrative references are found to be sometimes used instead of personal reference in both AST and FTT, for example:

Table 6.1.1.1 Abstractness

\begin{tabular}{|c|c|c|}
\hline AST & ETT & FTT \\
\hline 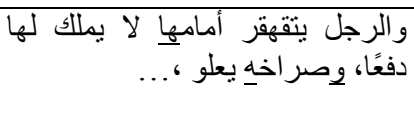 & $\begin{array}{l}\text { The man collapsed in front of } \underline{\text { her }} \text {, } \\
\text { offering no defence at all. } \underline{\text { His }} \text { wails } \\
\text { reverberated... }\end{array}$ & $\begin{array}{l}\text { L'homme battait en retraite sans } \\
\text { pouvoir se défendre et ses cris } \\
\text { perçants.... }\end{array}$ \\
\hline - -653-654 العفو والرحمة يا معلّمة... (ص. & $\begin{array}{l}\text { "Have forgiveness and mercy on him, ... } \\
\text { (p.27). }\end{array}$ & $\begin{array}{l}\text { - Un peu de clémence, patronne! } \\
\text { De la miséricorde! (p.43-44). }\end{array}$ \\
\hline
\end{tabular}

The personal reference, 'her' refers concretely to Husniya in the English extract; in the Arabic extract it is not cohesive because of the use of syndeton; but in the French extract, it is understood abstractly through the context. Moreover, 'him' in the English extract refers concretely to Jaada, whereas in the Arabic and French extracts it is understood abstractly. Abstractness does occur in the ETT but not often like the case in the AST and FTT.

Table 6.1.1.2 Syndeton

$\begin{array}{lll}\text { AST } & \text { ETT }\end{array}$

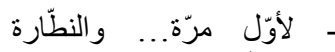

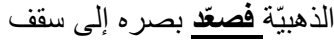

القهوة... (ص. 643 ) ). ....first time. He turned his gaze to

the café's roof... (p. 6).
..., se mit à bouger et son regard s'éleva

vers le plafond.(p.16). 
Another factor that affects personal reference is syndetic occurrence. It makes personal reference play an internal role, which is not cohesive. By comparison, the ETT is more cohesive in personal reference due to the use of short sentences punctuated by full stops, which cause the personal reference to play an external role.

In both Arabic and French extracts, the personal reference is internal and not cohesive, and that is caused by the use of coordinaton (syndeton). That is, the sentences in the Arabic extract are linked by the coordinator, iand in the French extract, the sentences are coordinated by' $e t$ '. By contrast, in the English extract, the personal reference is cohesive because it presupposes an element beyond its respective sentence. Syndeton does occur in the ETT but not often compared to the AST and FTT.

Table 6.1.1.3 Asyndeton

\begin{tabular}{|c|c|c|}
\hline AST & ETT & FTT \\
\hline 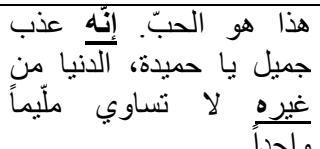 & $\begin{array}{l}\text { This is love. It is something rare and } \\
\text { beautiful, Hamida. Without it, the } \\
\text { whole world means nothing."... }\end{array}$ & $\begin{array}{l}\text { C'est cela l'amour. } \underline{\boldsymbol{I l}} \text { est doux et beau, } \\
\text { Hamida. Le monde sans } \underline{\text { lui }} \text { ne vaut pas un } \\
\text { millime... }\end{array}$ \\
\hline 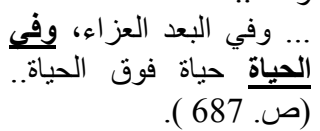 & $\begin{array}{l}\text {..It gives us a life that is far more } \\
\text { than life itself" (p. 93). }\end{array}$ & $\begin{array}{l}\text {... la peine quand on est séparés, il est dans la } \\
\text { vie une vie qui est plus que la vie (p. 135-6). }\end{array}$ \\
\hline
\end{tabular}

In the Arabic extract, personal reference is affected by the use of asyndetic structure and abstractness. The use of comma coordinates the sentences, and so the personal reference, '- - 'refers to an element, 'o' (it) in the same sentence. At the end of the sentence there is an abstract occurrence, and the sentence, في البعد العزاء، وفي الحياة حياة فوق الحئ، eliminates the personal reference. In the French extract, personal reference is also affected by the use of asyndeton. The use of a comma makes the personal reference, ' $i l$ ' be internal and it is, therefore, not cohesive. By contrast, a personal reference is cohesive in the English extract due to the lack of coordination and abstractness.

Table 6.1.1.4 Hypothaxis

\begin{tabular}{|c|c|c|}
\hline AST & ETT & FTT \\
\hline 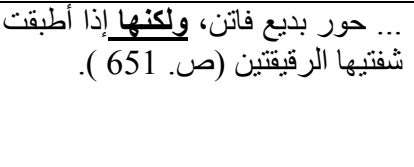 & $\begin{array}{l}\text {... and attractive way. When, however, } \\
\text { she set her delicate lips and narrowed her } \\
\text { eyes ...(p.21). }\end{array}$ & $\begin{array}{l}\text {... ses beaux yeux d'un noir profond } \\
\text { et charmeur, qui pourtant, quand } \\
\text { elle serrait ses lèvres minces et } \\
\text { aiguisait son regard, ...(p.36). }\end{array}$ \\
\hline
\end{tabular}

In the Arabic extract, personal reference is affected by the use of syndeton, which makes the personal reference be internal and so not cohesive. However, in the French extract, personal reference is affected by the use of hypotaxis (using subordinating conjunctions). The personal reference, 'elle', therefore, is not cohesive because it plays, due to hypotaxis, an internal function. By contrast, the personal reference- 'she', in the English extract, is cohesive because it presupposes an element outside its respective sentence. That reflects the English affection of using short sentences. This happens elsewhere in the texts as it is presented in the appendices.

Table 6.1.1. 5 Interchangeability

\begin{tabular}{|c|c|c|}
\hline AST & ETT & FTT \\
\hline 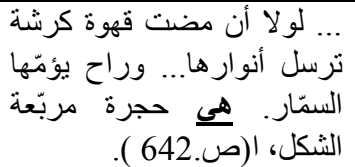 & $\begin{array}{l}\text { The café is beginning to fill with } \\
\text { customers. It is a square room, ...(p.3). }\end{array}$ & $\begin{array}{l}\text {... si le café Karcha... n'avait été le } \\
\text { point de ralliement des veilleurs. } \\
\underline{\text { C'était une salle carrée,... (p. 11). }}\end{array}$ \\
\hline
\end{tabular}

In the above extracts, personal references, 'هي' in the AST and 'it' in the ETT, are used to refer to the nominal compound, 'anهة كرشة 'the café', but in the French extract, a demonstrative reference, 'ce' is used. This case of personal reference and demonstrative reference exchange is found elsewhere in the texts as it is presented in the appendices.

6.1.2 Demonstrative reference

Table 6.1.2.1.Abstractness

\begin{tabular}{|c|c|c|}
\hline AST & ETT & FTT \\
\hline 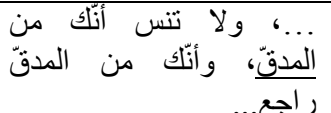 & $\begin{array}{l}\text { Never forget that you c } \\
\text { alley, and it's here you w }\end{array}$ & $\begin{array}{l}\text { Et n'oublie pas que tu es de l'impasse du } \\
\text { Mortier et que tu y reviendras... }\end{array}$ \\
\hline 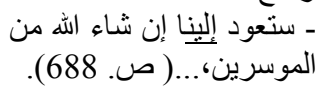 & $\begin{array}{l}\text { If God wills, you will return here a rich } \\
\text { man, ... (p. 95). }\end{array}$ & $\begin{array}{l}\text { - Tu nous reviendras riche, s'il plaît } \\
\text { Dieu } \\
(p .138) .\end{array}$ \\
\hline
\end{tabular}

In the Arabic extract and the French extract, there is no concrete demonstrative reference, which refers to the previously occurred noun, the alley. The use of إلينا(to us) and nous (to us) make it abstract. By contrast, the demonstrative referent, 'here' used in the English extract coheres with the word, alley. The reader understands directly that the place which Dr. 
Booshy is talking about is concretely the alley. Abstractness and other factor like syndeton, and asyndeton are found to affect also demonstrative reference. They occur elsewhere as it is presented in the appendices.

Table 6.1.2.2 Interchangeabillity

\begin{tabular}{|c|c|c|}
\hline AST & ETT & FTT \\
\hline 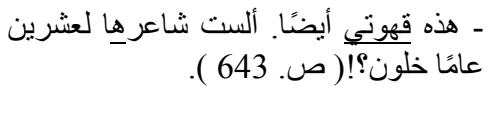 & $\begin{array}{l}\text { "This is my café too. Haven't I } \\
\text { been reciting } \underline{\text { here for the last }} \\
\text { twenty years?" (p. 5). }\end{array}$ & $\begin{array}{l}\text { - C'est mon café aussi. Ne suis-je } \\
\text { pas son poète attitré depuis vingt } \\
\text { ans? (p. 15). }\end{array}$ \\
\hline
\end{tabular}

Personal references and reiteration are sometimes interchangeable with demonstrative reference. However, the ETT, like the AST, use more personal reference than the FTT, which prefers more demonstrative reference. All the cohesive ties in the above extracts are cohesive in that the references cohere with referents in other sentences. Unlike the English extract, which uses the demonstrative reference, 'here', the French and Arabic extracts use personal references, 'son' and 'ه'. Reiteration is, in the AST and FTT, interchanged with demonstrative reference in the ETT. These cases have been found to occur elsewhere as it is presented on the appendices.

\subsubsection{Comparative reference}

Table 6.1.3.1. Comparative reference

\begin{tabular}{|c|c|c|}
\hline AST & ETT & FTT \\
\hline أوّل ما نبتدي اليوم نصلَّي & "We are going to begin today by saying a & - Nous commencerons d'abord aujourd'hui \\
\hline 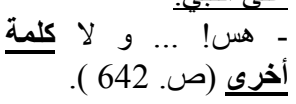 & $\begin{array}{l}\text { "Shut up! Don't say a single word } \\
\text { more!" (p. 5) }\end{array}$ & - Silence! Et pas un mot de plus (p. 14). \\
\hline
\end{tabular}

The ETT uses more comparative reference than the AST and the FTT, which sometimes use other cohesive ties. In the above extract, there is a literal translation of comparative reference. The highlighted words presuppose comparatively the underlined statements in the Arabic, English, and French. The difference is not of cohesive category change but of word class change, transposition. The comparative referent (أخرى) in the Arabic source extract is an adjective, whereas in the target extracts the comparative references, more and plus are adverbs. Anyhow, they all achieve the same cohesive effects. Literal translation of comparative reference occurs elsewhere on pages 43, and 111 of the ETT; and pages 67, and 159 of the FTT. They correspond to pages 662 and 669 of the AST. However, there is interchangeability between personal reference and reiteration in the AST, ellipsis in the FTT, and comparative reference in the ETT. It occurs elsewhere as it is presented on the appendices.

All in all, the ETT tend to use more comparative reference than AST and FTT. Therefore, it shifts from some cohesive ties like personal reference, demonstrative reference, reiteration, and ellipsis that occurred in the AST. Compared to the ETT, the FTT tends to use more ellipsis as far as this category is concerned.

6.2 Mawsim el-Hiğrailā ash-Shamāl

6.2.1. Personal reference

The ETT is more cohesive than the FTT and AST in terms of personal reference due to concreteness and conciseness. In the FTT, personal reference is affected often by abstractness. In the AST, personal reference is affected, often, by the use of syndeton and implicitness. For example:

\subsubsection{Abstractness}

AST

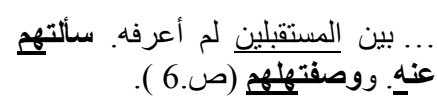

ETT

... a face I did not know among those who had been there to meet me. I asked about him, described him to them (p.2).
FTT

...un visage parmi ceux qui étaient venus m'accueillir. Visage d'un inconnu dont je fis la description : (p. 10).

In the AST, the personal reference- srefers back to the noun, المستقبلينland the second personal reference ' - o' refers cohesively to the previously occurred noun, وجها. The use of a second independent sentence, i.e. وها cohesiveness to the sentences since all the references refer to referents outside the sentence. The English extract is also characterized by cohesive references. The reference, 'him' refers to the noun, 'a face' in the previous independent sentence. The personal reference, 'them' also does the same. It refers to the word, 'those'. However, in the French extract, personal reference is affected by the use of another cohesive tie, i.e. reiteration and abstractness. The word, 'visage' is repeated in the second sentence instead of a personal reference like the case in the Arabic extract and English extract, and it is still cohesive. However, the sentence, 'dont je fis la description' is abstract. There is no reference that 
goes back to the previous noun. It is inferred abstractly that the description is done to the word, 'ceux'. Such abstract occurrences do affect personal reference. This cases are found to occur elsewhere in the texts as it is presented in the appendices.

Table 6.2.1.2. Syndeton

\begin{tabular}{|c|c|c|}
\hline AST & ETT & FTT \\
\hline 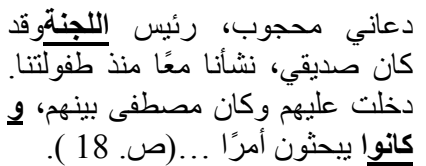 & $\begin{array}{l}\text { When I entered, I found that Mustafa } \\
\text { was a member of the Committee. They } \\
\text { were looking into ...(p. 12). }\end{array}$ & $\begin{array}{l}\text { Je fus prié d'assister à une } \\
\text { réunion ... du comité d'initiative } \\
\text { agricole... Moustafa était là. Ils } \\
\text { discutaient...(p. 19). }\end{array}$ \\
\hline
\end{tabular}

In the Arabic extract, the personal reference which is $ه$ is implicit in the last sentence ; it is not cohesive because the sentence is coordinated by the use of a coordinating conjunction, which is ' $g$ '. This makes it play an internal role. By contrast, in the English and French extracts, the personal references used are cohesive because they cohere with the nouns, 'committee' and 'comité' in another sentence. This makes them cohesive because they play an external role beyond their respective sentences.

Table 6.2.1.3 Asyndeton

\begin{tabular}{|c|c|c|}
\hline AST & ETT & FTT \\
\hline عجيية أن وجئن كانت لحظة حقيقة & $\begin{array}{l}\ldots \text { and it was an extraordinary moment } \\
\text { when I at last found myself standing }\end{array}$ & $\begin{array}{l}\text {.. tels que ce fut merveilleux de me } \\
\text { trouver réellement parmi eux. Ils en }\end{array}$ \\
\hline 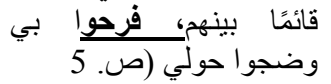 & $\begin{array}{l}\text { amongst them. They rejoiced at having me } \\
\text { back and made a great fuss... (p. } 1) \text {. }\end{array}$ & $\begin{array}{l}\text { firent une fête d'interjections et } \\
m \text { 'entourèrent }(p .9) \text {. }\end{array}$ \\
\hline
\end{tabular}

Asyndeton is found to affect personal reference. It coordinates sentences by the use of comma and semi colon, which turn it into internal function. It is found to occur in the AST and TTs, and it is a writer/translator's choice.

Personal reference is affected in Arabic extract in that the second sentence is coordinated to the first sentence by the use of a comma, which turns the personal reference to be internal. The implicit personal reference refers to preceded personal pronoun in جئن but it lost cohesiveness due to the use of coordination. By contrast, in the English extract the personal reference, 'they' coheres with the personal pronoun, 'them' which occur in the preceding sentence. The same happens in the French extract. The personal pronoun, 'ils' coheres with the personal pronoun, 'eux' which occurs in the preceding sentence. The reference cohesiveness in both English and French extracts is due to the fact that the references and the referents occur in different non coordinated sentences. This has been found to occur elsewhere as it is presented in the appendices.

Table 6.2.1.4 Hypothaxis

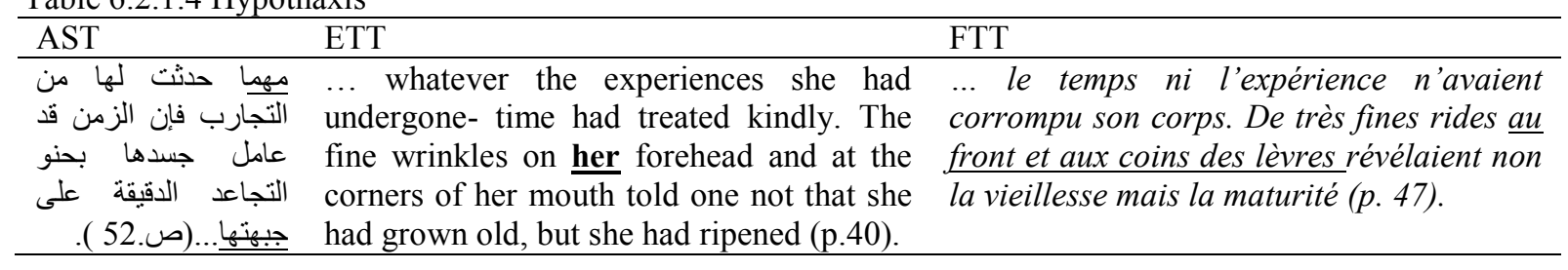

Hypotaxis is found to affect personal reference. It is found to occur in the AST and TTs. It depends more on the translator's sentence structure choice. In the Arabic extract, the personal reference, which is $ه$, is not cohesive because it is in a clause linked to another clause by a subordinating conjunction, 'مهما'. It, therefore, turns it into an internal function. In the English extract, the second sentence is separated from the first one. The personal reference, therefore, presupposes an external element. This has caused it to be cohesive. In the French extract, the sentences are separated like the case in the English extract, but the personal reference does not appear in its respective location in the phrase, au front et aux coins des lèvres; it is therefore abstract. This case is found to occur elsewhere in the AST on pages 173, and 188.

Table 6.2.1.5. Interchangeability

AST

ETT

FTT

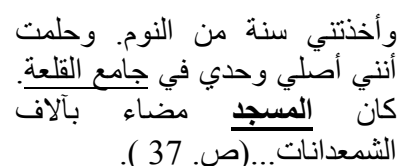

الشمعدانات...(ص). 37 ).
Falling into a short sleep, I dreamt I was praying alone at the Citadel Mosque. It was illuminated with thousands of chandeliers... (p. 28).
Je m'assoupis et rêvai que j'étais seul dans la mosquée de la Citadelle, illuminée de milliers de candélabres... (p. 35). 
It is found that French is excessive in using demonstrative reference compared to the AST and ETT. In the above table, a reiteration is used in the Arabic extract instead of a personal reference, and it is still cohesive. The reiteration is done by the use of a synonym. مسجد However, in a synonym of English extract a personal reference, 'it' is used instead of reiteration to cohere with the noun phrase, 'the Citadel Mosque'. In the French extract neither a reiteration nor a personal reference is used. The use of a mere past participle, 'illuminée' after a comma makes it abstract. No cohesive marker that coheres it with the preceding noun. It is up to the reader to infer abstractly that the illumination is about the mosque. This happens elsewhere on pages 25, 103, and 110 of the AST. Interchangeability occurs also elsewhere as it is presented in the appendices.

6.2.2 Demonstrative reference

6.2.2.1. Abstractness

\begin{tabular}{|c|c|c|}
\hline AST & ETT & FTT \\
\hline "لا، إنها لن تقول عجيب" لا. وقالت: & $\begin{array}{l}\text { No, she would not say no. "This is an } \\
\text { extraordinary meeting," she said (p. } 40) \text {. }\end{array}$ & $\begin{array}{l}\text { En tel état, je savais que j'étais } \\
\text { maître de la situation. Elle dit: " } \\
\text { Etrange rencontre »(p.46). }\end{array}$ \\
\hline
\end{tabular}

Abstractness in the FTT affects more the cohesiveness of demonstrative reference. In the AST, the demonstrative reference, هذاcan be said to refer to preceded sentences, which are: ما رأيك في أن نتمشى معًا، ونواصل الحديث. The same happens in the English extract. The demonstrative reference, 'this' refers to the previous underlined sentences, which are: "What would you say to having dinner together and continuing the conversation?" By contrast, in the French extract there is no cohesive marker in the sentence that supposed to cohere with the first underlined sentences. It appears abstract in the noun phrase 'Etrange rencontre'. It is only understood abstractly that this strange meeting is their coming together to have dinner. Other factors that affect demonstrative reference are syndeton and asyndeton, which occur in the texts as they are presented in the appendices.

\subsubsection{Interchangeability}

\begin{tabular}{|c|c|c|}
\hline AST & ETT & FTT \\
\hline 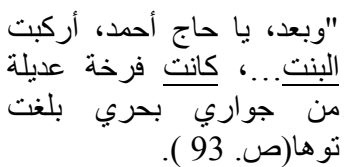 & $\begin{array}{l}\text { 'And afterwards, Hajj Ahmed, I put the } \\
\text { girl ... She was a young slave girl from } \\
\text { down-river who'd just reached puberty' p. } \\
\text { 74). }\end{array}$ & $\begin{array}{l}\text { - Alors Hadj Ahmed, je pris la fille.... } \\
\text { C'est une jeune esclave originaire de } \\
\text { l'aval du fleuve, déjà nubile (p. } 77- \\
78) .\end{array}$ \\
\hline
\end{tabular}

It is found also that other cohesive ties are used instead of demonstrative reference. In the Arabic extract, an implicit personal pronoun, البنت هي refers to the noun, but is not cohesive because it is in a sentence that is coordinated by asyndeton. The same happens in the English extract. The personal reference, 'she' is used to refer to the noun, 'the girl'; it is cohesive because the reference and the referents occur in non-coordinated sentences. However in the French extract, a demonstrative reference, ' $c e$ ' is used to cohere with the noun, 'la fille'. There is also interchangeability between reiteration in the FTT and demonstrative reference in the AST and ETT, which occur elsewhere as presented in the appendices.

6.2.3 Comparative reference

Table 6.2.2.3.1 Comparative reference

\begin{tabular}{|c|c|c|}
\hline AST & ETT & FTT \\
\hline 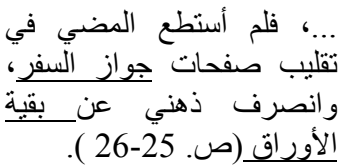 & $\begin{array}{l}\text { I could not go on turning over the pages of } \\
\text { the passport. Neither was I particularly } \\
\text { interested in looking at the other papers } \\
\text { (p.18). }\end{array}$ & $\begin{array}{l}\text { Je lus un feuillet, c'était l'acte de } \\
\text { naissance... Tout cela m'excita au } \\
\text { point que je ne pus poursuivre plus } \\
\text { avant ma lecture (p. 24-5). }\end{array}$ \\
\hline
\end{tabular}

It is found that the ETT is excessive in using comparative reference compared to the AST and FTT, which are found to use them sparingly. In the Arabic extract, there is no comparative reference. The word, 'بقية'is not a comparative reference. It literally means the remains or the rest. So the whole phrase, 'بقية الأوراق' is a reiteration; but it is not cohesive because the comparative reference and the referent are internal due to the use of coordination by way of a syndeton. It is, therefore, abstract. This also occurs on page 14 of the AST. It corresponds to page 9 of the ETT and 17 of the FTT.

However, in the English extract, a comparative reference is used instead of a reiteration. The comparative reference, 'other' is cohesive because it compares an element in a different sentence. The occurrence 'other paper' gives a comparison to the referent, 'passport'. Like the Arabic extract, the comparative reference in the French extract is 
playing an internal role. This is because the translator has combined two sentences in one sentence, and the sentences read 'I could not go on turning over the pages of the passport. Neither was I particularly interested in looking at the other papers', whereas in the FTT the sentences are combined and read, tout cela m'excita au point que je ne pus poursuivre plus avant ma lecture. Such a shift occurs also on page 28 of the AST, 20 of the ETT, and 27 of the FTT.

\subsection{Translation Modelling}

In this modeling figure, O. F. is the abbreviation the researcher gives to occurrence frequency (O.F).

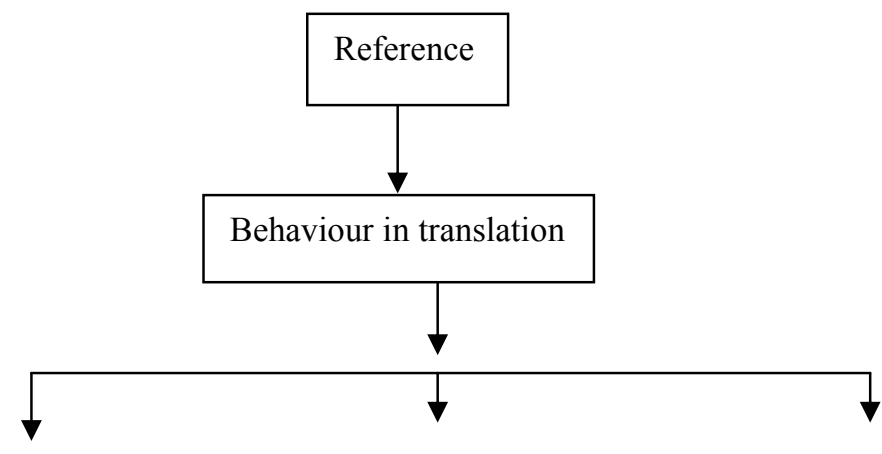
O.F in ASL
O.F in ETL
O.F in FTL

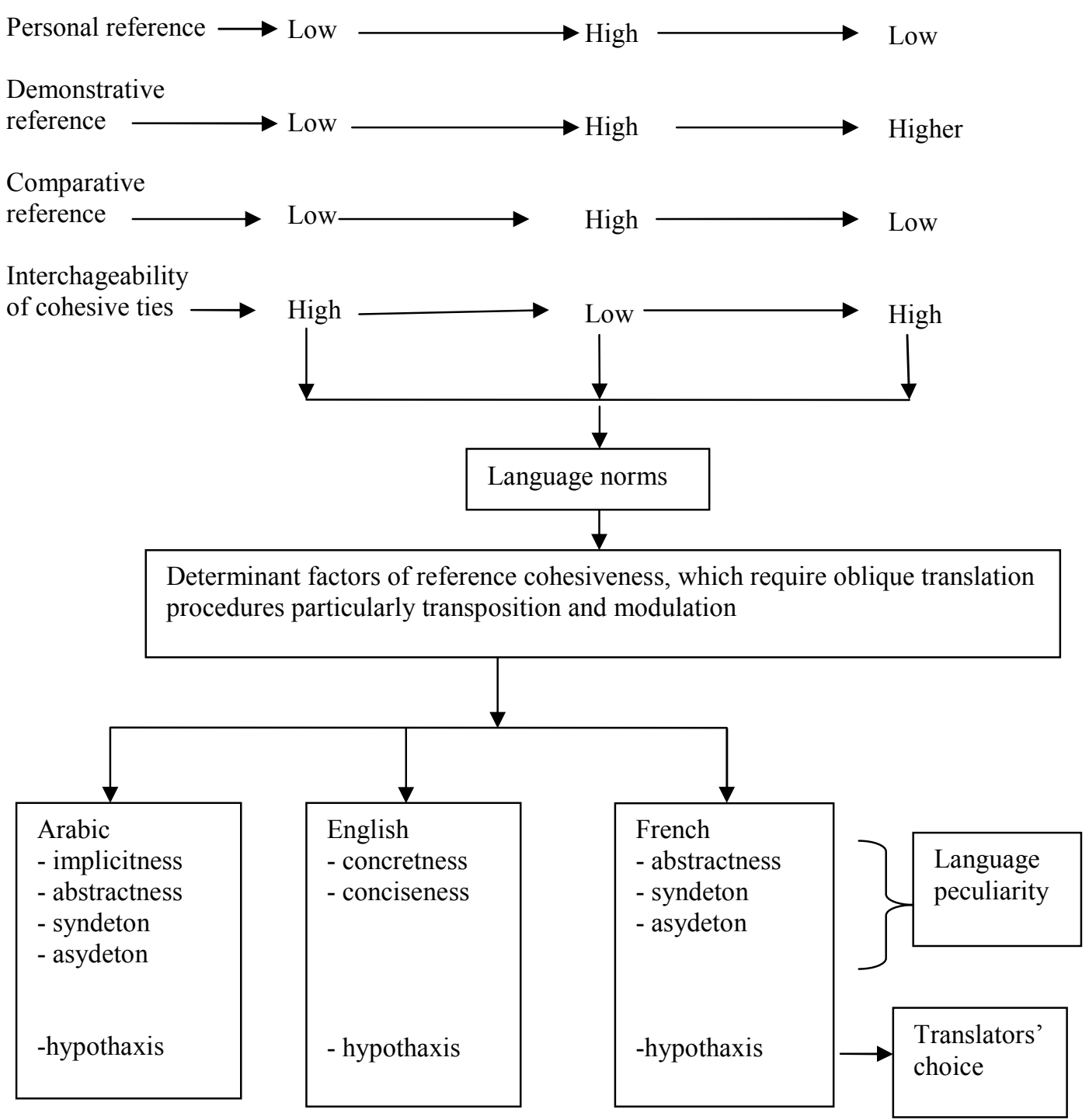

\section{Conclusion}

It is found that cohesion in terms of reference is affected by abstractness, the use of coordinating conjunctions, the use of coordinating punctuations, the use of subordinating conjunctions, and implicitness of the subject. It is enhanced by the use of short sentences and concreteness.

Reference is more affected in the ASTs by the excessive use of abstractness, coordinating conjunctions, coordinating punctuations, and implicitness of the subject. They are found to be peculiar aspects of Arabic discourse. The aspect of abstractness and subject implicitness reduces the occurrences of cohesive ties, whereas coordinating conjunctions and coordinating punctuations make the reference play an internal role in the sentences, which is not cohesive. In the FTT, 
reference is more affected by abstractness, coordinating conjunctions, coordinating punctuations, and subordinating conjunctions. Abstractness reduces reference occurrences, whereas coordinating conjunctions, coordinating punctuations, coordinating punctuations, and subordinating conjunctions make the reference play an internal role in the sentences, which is not cohesive. These aspects are peculiar to the French language rather than the translators' choices of decisions. However, reference is more enhanced in the ETTs due to concreteness and the use short sentences. Those aspects reflect the nature of the English language rather than the translators' choices of decisions. This shows that English does not leave the receptor to infer reference occurrences as it happens with Arabic and French languages; it does not also rely excessively on long and complex sentences.

It is found also that there is interchangeability among the subcategories of reference. English language diversifies the use of the three categories of reference, i.e. personal reference, demonstrative reference, and comparative reference. It often uses them for cohesive purposes. Nevertheless, Arabic language depends more on the use of personal reference and reiteration; it uses sparingly comparative references. French language also is characterised by the use of demonstrative references and other cohesive ties like reiteration and ellipsis; it uses sparingly comparative references.

\section{References}

Allen, R. (1997). Najib Mahfouz. In African Writers (vol. 2). Brian, C., ed., p. 451- 465. New York: Charles Scribner's Sons.

Baker, M. (1992). In other words: A coursebook on translation. London and New York: Routledge.

Blum-Kulka, S. (2000).Shifts of cohesion and coherence in translation.In The translation studies reader. Venuti, L, ed., p. 298-313. London: Routledge.

Callow, K. (1974).Discourse considerations in translating the word of God. Michigan: Zonderran.

Cary, E. (1963). L’indispensabledébat.In La qualitéenmatière de traduction.Cary, Eand Jumpelt, R. W., p. 21-48. Oxiford :Pengamon Press.

Catford, J. (1965).A linguistic theory of translation: An essay in applied linguistics. London: Oxford University Press. Charolles, M. (1978).Introduction aux problèmes de la cohérence des textes, La Journal de la Langue Française38 : 7 38.

Enkvist, N. E., Academi, Å. and Finland, Å. (1990).Seven problems in the study of coherence and interpretability.In Coherence in Writing.Connor, Uand Johns, A, eds., p. 11-26. Alexandria and Virginia: TESOL.

Evan-Zohar, I. (2000). The position of translated literature, within the literary polysystem.In The translation studies reader. ed. V. Lawrence, V. ed, p. 192-197. London and New York: Routledge.

Halliday, M. A. K. (1978). Language as Social Semiotic: the Social Interpretation of Language and Meaning. Baltimore: University Park Press.

Halliday, M. A K..(1985).An introduction to functional grammar. London: Edward Arnold.

Halliday, M. A. K. and Hasan, R. (1976).Cohesion in English. London: Longman.

Holmes, J. S. (2000). The name and nature of translation studies.In The Translation Studies Reader. Lawrence, V. ed., p. 172-185. London and New York: Routledge.

Lambert, J. and van Gorp, H. (1985). On describing translations. In The Manipulation of Literature: Studies in Literary Translation.Hermans, T., ed., p. 42-53. New York: ST. Martin’s Press.

Leech.G. (2008).Language in Literature: Style and Foregrounding. Harlow: Pearson Education Limited.

Moindjie, M. A. (2003).An investigation into the aspect of coherence and cohesion in Translation: A case study. MA diss., UniversitiSains Malaysia.

Moindjie, M. A.(2006).A comparative study of literary translation from Arabic into English and French. PhD diss., UniversitiSains Malaysia.

Munday, J. (2001). Introducing translation studies: theory and applications. London and New York: Routledge.

Popovič, A. (1970). The concept 'shift of expression' in translation analysis. In The nature of translation: Essays on the theory and practice of literary translation.Shilmes, J, Haan, F and Popovič, A., eds 78- 87. Mouton: Slovak Academy.

Sadgrove, P. (1997). Al- TayyibSālih. In African Writers (vol. 2). Brian, C., ed., p. 733-744. New York: Charles Scribner's Sons.

Toury, G. (1985). A rationale for descriptive translation. In The Manipulation of Literature: Studies in Literary Translation. Hermans, T., ed., p. 16-41. New York: ST. Martin's Press.

Toury, G. (1995).Descriptive translation studies and beyond. Amsterdam and Philadelphia: John Benjamins Publishing Company.

Trask, R.L. (1997). A Student's Dictionary of Language and Linguistics. London: Arnold.

Vinay, J. and Darbelnet, J. (1995).Comparative Stylistics of French and English: AMethodology for Translation (J. C. Sager and M. J. Hamel, Trans.). Amsterdam and Philadelphia: John Benjamins Publishing Company.

\section{Corpora used}

Notes

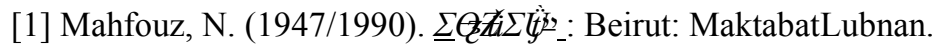

[2] Mahfouz, N. (1975). Midaq Alley (T. Le Gassick, Trans.). London: Heinemann.

[3] Mahfouz, N. (1970). Passage des Mirracles (A. Cottin, Trans.). Paris: Ėditions Sindbad.

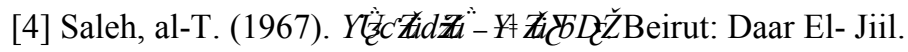


[5] Salih, al-. (1969). Season of Migration to the North (D. Johnson-Davies, Trans.). London: Heimann.

[6] Salih, al-. (1983). Saison de la Migration Vers le Nord (A. Meddeb and F. Noun, Trans.).Paris:Sindbad.

\section{Appendices}

Pages Number of Occurrences in the Texts

1.Zukak el-Midaq, translated as MidaqAlley,andPassage des Miracles.

Abstractness

\begin{tabular}{|c|c|c|}
\hline $\begin{array}{l}\text { Pages of the Arabic Extracts } \\
641-771\end{array}$ & $\begin{array}{l}\text { Pages of the English Extracts } \\
22-230\end{array}$ & $\begin{array}{l}\text { Pages of the French } \\
\text { Extracts } \\
7-337\end{array}$ \\
\hline
\end{tabular}

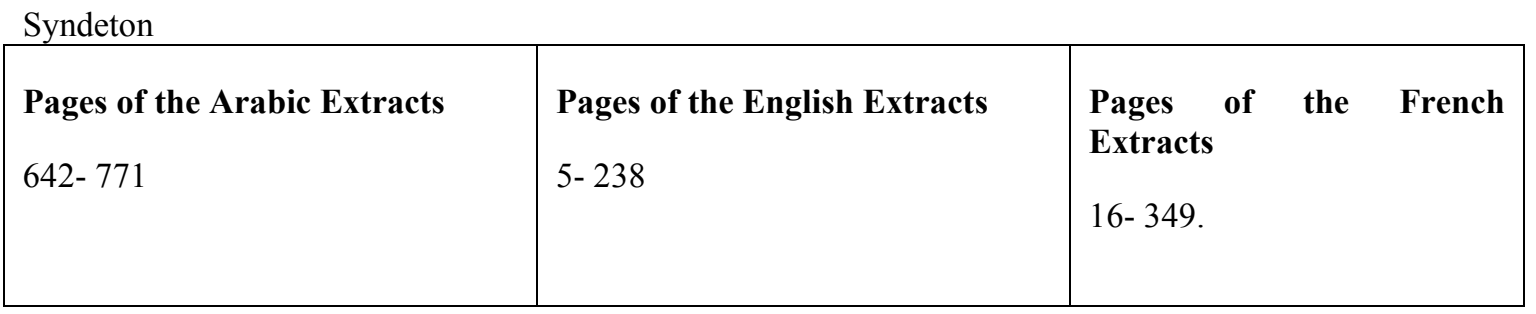

Asyndeton
\begin{tabular}{|l|l|l|}
\hline Pages of the Arabic Extracts & Pages of the English Extracts & $\begin{array}{l}\text { Pages of the French } \\
\text { Extracts }\end{array}$ \\
$25-236$ & $11-349$. \\
\hline
\end{tabular}

\begin{tabular}{|c|c|c|}
\hline $\begin{array}{l}\text { Pages of the Arabic Extracts } \\
654-771\end{array}$ & $\begin{array}{l}\text { Pages of the English Extracts } \\
\text { 22- } 218\end{array}$ & $\begin{array}{l}\text { Pages of the French } \\
\text { Extracts } \\
32-349\end{array}$ \\
\hline
\end{tabular}

Interchangebility
\begin{tabular}{|l|l|l|} 
Affected Pages of the Arabic & Pages of the English Extracts & $\begin{array}{l}\text { Pages of the French } \\
\text { Extracts }\end{array}$ \\
$642-771$. & $6-236$ & $20-349$ \\
\hline
\end{tabular}

2.Mawussim el-HijratilaShimal_translated as_Season of Migration to the North, Saison de la Migration vers le Nord Abstractness

\begin{tabular}{|c|c|c|}
\hline $\begin{array}{l}\text { Pages of the Arabic Extracts } \\
126,127,190 \text {, and } 192\end{array}$ & $\begin{array}{l}\text { Pages of the English Extracts } \\
\text { 2- } 164\end{array}$ & $\begin{array}{l}\text { Pages of the French } \\
\text { Extracts } \\
10-169\end{array}$ \\
\hline
\end{tabular}

\begin{tabular}{|c|c|c|}
\hline $\begin{array}{l}\text { Pages of the Arabic Extracts } \\
\text { 34- } 197\end{array}$ & $\begin{array}{l}\text { Pages of the English Extracts } \\
\text { 14- } 161\end{array}$ & $\begin{array}{l}\text { Pages of the French } \\
\text { Extracts } \\
38-166\end{array}$ \\
\hline
\end{tabular}


Asyndeton

\begin{tabular}{|l|l|l|}
\hline Pages of the Arabic Extracts & Pages of the English Extracts & $\begin{array}{l}\text { Pages of the French } \\
\text { Extracts }\end{array}$ \\
$5-193$ & $1-164$ & $9-87$ \\
\hline
\end{tabular}

Hypothaxis
\begin{tabular}{|l|l|l|} 
Pages of the Arabic Extracts & Pages of the English Extracts & $\begin{array}{l}\text { Pages of the French } \\
\text { Extracts }\end{array}$ \\
173, and 188 & $13-164$ & $10-166$. \\
\hline
\end{tabular}

Interchangeability
\begin{tabular}{|l|l|l|}
\hline Pages in the Arabic Extracts & Pages in the English Extracts & $\begin{array}{l}\text { Pages in the French } \\
\text { Extracts }\end{array}$ \\
$2-195$ & $2-158$ & $20-164$ \\
\hline
\end{tabular}

